\title{
A Universidade e a Pesquisa
}

Repercutiu consideravelmente a divulgação da análise do nível de qualificação dos docentes das Universidades brasileiras e que vem sendo realizada pelo Ministério da Educação e do Desporto. O critério básico adotado foi o relativo à titulação do corpo docente de 106 instituições de ensino superior. Claro está que as reaçðes, em que pese feição comum favorável à citada análise, foram bastante variadas, principalmente aquelas à procura de justificativas para as instituiçð̃es desfavoravelmente posicionadas na classificação geral daí resultante. De qualquer maneira, se a qualificação docente pode ser tida como decorrência da produção acadêmica, há que se definir esta a partir do famoso "tripé" universitário, istoé, o ensino, a pesquisa e a prestação de serviços à comunidade. E, ao que parece, é a respeito da segunda que mais se acirram as polêmicas.

É ponto pacífico que ao longo deste século, ora prestes a se findar, o ser humano assistiu a tão drásticas transformações que se tornou difícil entender, em sua plenitude, as extraordinárias mudanças do estilo de vida resultantes do desenvolvimento científico e da tecnologia daí decorrente. Está-se tão imbuído do presente conceito de humanidade que é atualmente difícil entender a escala do tempo de evolução da espécie humana e o quão recentemente ela existe na terra. Tendo-se separado dos antropóides há cerca de 5 a 10 milhões de anos, só há aproximadamente 10.000 anos deixou o nomadismo e a prática da caça e coleta como meios únicos de sobrevivência. A acentuada tendência de crescimento e dispersão do desenvolvimento industrial atingiu nível extremamente elevado no século 20 , a ponto de hoje ser praticamente impossível imaginar a existência de um mundo sem o artificialismo que daí se originou. E mais, chegou-se à situação em que, para se manterem e mesmo sobreviverem com liderança política, os países necessitam de investir cada vez mais em tecnologia. Conseqüentemente, e também cada vez mais, requer-se número maior de pesquisadores bem formados. E é, em especial modo, nas universidades que se encontra a sede natural da pesquisa de novos conhecimentos. Caberá pois, em tese, toda uma política governamental de alocação de recursos para o desenvolvimento da ciência básica no âmbito universitário (Hackerman, 1984).

Posto isso, é de se perguntar se a titulação do professor de terceiro grau no Brasil e que serviu de base para a referida análise, não estaria de algum modo ligada à política de alocação de recursos para a pesquisa básica nas Universidades. A acentuada expansão das instituições de ensino superior que se observou em nosso País por ocasião do decênio dos anos setenta, teve a sua parte de influência na baixa qualificação do corpo docente. Por isso muito contribuiu a pouca seletividade no recrutamento, daí resultando situações de acomodação em níveis de qualificação insuficiente, denominados por alguns de professores "corporativos" (Schwartzamn e Balbechevsky, 1994). Por outro lado, é de se admitir que a atividade científica não possa medrar em ambientes destituídos de mecanismos de avaliação que não devem ser exclusiva ou preponderantemente endógenos ou de natureza corporativa. Tal avaliação, por sua vez, só tem sentido quando existe disponibilidade de recursos para a pesquisa. Estabelece-se, assim, círculo vicioso, ou seja, não se faz pesquisa porque não há recursos, humanos e materiais, e estes não são alocados porque não se faz pesquisa.

A questão dos recursos apresenta feições de cronicidade às quais têm-se voltado ampla bibliografia. Mesmo nos países do assim chamado primeiro mundo, o sistema universitário de pesquisa atingiu vulto e custos que não podem mais ser sustentados apenas pelos orçamentos institucionais. Daí a procura de fontes complementares representadas pelo sistema empresarial privado, para que a diminuição da pesquisa não vá se refletir em fenômeno análogo em relação ao ensino (Maddox, 1994). Mas, quais seriam então as perspectivas para o Brasil? Como a pesquisa universitária poderia sobreviver enfrentando todas essas dificuldades?

Desde que é impossível considerar aqui todos os óbices, há que se ter em mente a necessidade de desenvolvimento científico autócne. Seja qual for a fonte dos recursos, não se consegue vislumbrar, de maneira inequívoca, plano nacional de ciência e tecnologia que seja harmônico e com prioridades bem definidas. O que se faz, de rotina e sem se aprofundar muito nesse aspecto, é enviar os nossos jovens a se especializarem em países do primeiro mundo e dos quais voltam para transmitir o que aprenderam. Na verdade, esse aprendizado limitase, a mais das vezes, aos aspectos tecnológicos e pois, geralmente não se motivam em dar continuidade teórica à especialidade que abraçaram. No mais, isso sim, importamos tecnologia representada por procedimentos, equipamentos, implementos, reativos, etc., pagando os devidos "royalties" e custos de importação e de manutenção. Diante desse quadro, é ilusório esperar o estabelecimento de metas prioritárias de pesquisa. $\mathrm{Na}$ verdade, como se confunde ciência básica com tecnologia e esta, como se referiu, encontra-se disponível para importação, não há motivos para desenvolver aquela. Como resultado, são freqüentes as visitas de estudantes e mesmo especialistas estrangeiros que vêm fazer observações e coletar material para suas pesquisas, a serem feitas e divulgadas em seus países de origem. Como exemplo, pode-se mencionar estudos da fauna amazônica, que 
podem ser encontrados nas publicações científicas estrangeiras e às quais os nossos especialistas têm acesso bem mais tardio do que os seus colegas de outros países.

O atual quadro da qualificação docente das Universidades do Brasil e referido no início deste Editorial, deve ser considerado como um dos reflexos dessa situação. Pelo menos em parte, deve ser encarado como o descaso, oficial e particular, pelas atividades de pesquisa básica, isto é, aquelas que trazem novos conhecimentos passíveis de aplicação "a posteriori" e que, pela sua própria natureza, só podem ser levadas a efeito no âmbito universitário. Como resolver a contento os nossos problemas se não conhecemos antecipadamente a sua essência? Será através de soluções importadas? Estas, em geral não atendem às nossas necessidades, ou na melhor das hipóteses, precisam de ser adaptadas à nossa realidade.

Em resumo, a questão da qualidade docente e do ensino universitário no Brasil caracteriza-se em parte e de maneira panorâmica, pela falta de incentivos para a pesquisa básica. Todavia, há de se deixar bem claro que o provimento, puro e simples, dos recursos materiais e humanos, embora pré-requisitos, nem por isso são suficientes. Deve-se contar, imprescindivelmente, com o critério de mérito que seja adequado para a valorização do empenho e da ética profissionais. Em outras palavras, é necessário que se instale o sistema da meritocracia.

\author{
Oswaldo Paulo Forattini \\ Editor
}

\title{
Referências Bibliográficas
}

- HACKERMAN, N. Science is universal: the practioners are not. [Editorial] Science, 225(4662): 577, 1984.

- SCHWARTZAMAN, S. \& BALBACHEVSKY, E. Privilégio e dignidade. O Estado de São Paulo, São Paulo, p. A-16, 26 jul., 1994.

- MADDOX, J. Can the research university survive? Nature, 369: 703, 1994. 